\title{
横長開口から噴出する熱気流の鉛直壁面近傍温度分布 \\ TEMPERATURE DISTRIBUTION IN THE VICINITY OF VERTICAL WALL ON OPENING FIRE PLUME EJECTED FROM HORIZONTAL OPENING
}

\author{
大宮喜文*, 申 易 澈**, 野秋政希***, 姜 昇 具**** \\ Yoshifumi OHMIYA, Yi-chul SHIN, Masaki NOAKI \\ and Seung-goo KANG
}

\begin{abstract}
The focus of this research was placed on the shape of the plumes of hot air under various flammable material conditions for openings with a horizontal shape. A series of experiments using a full-size compartment focusing on the shape of the temperature distribution in order to obtain knowledge related to the shape of the temperature distribution were conducted. The following was found from the experimental results.: a)Temperature attenuated with height $Z$ above the opening to essentially the -1 power. b) The temperature distribution near the wall above the opening exhibited a correlation with the temperature distribution of the rectangular heat source in free space. c) Under the conditions where ethanol and heptane were used, $Q_{\mathrm{e}, \mathrm{f} \text { crit }}$ and $\mathrm{Q}_{\mathrm{ef}, \mathrm{e}}$ tended to match well.
\end{abstract}

Keywords : Horizontal opening, Rectangular heat source, Ejected flame, Temperature distribution, Pyrolysis gas 横長開口，長方形熱源，噴出火炎，温度分布，未燃ガス

\section{1. はじめに}

時代に応じて建築物に対する要求は変化し、建築空間の使われ方 や建築部位ごとの役割や機能等も変容している例えば 1) 5)。例えば、 採光や眺望などに対する要求から、ガラス面を大きくとるために 空・開口部の形状を横方向に長大化する事例が見られるようになっ た。また、建築物の省エネルギー化の要求もあり、空・開口部や建 築ファサードの断熱化が求められ、断熱性能の高いプラスチック系 の材料が素材として使用される例も見られる。一方、建築物を使用 する人々の生活様態などの変化から、建築物内に持ち込まれる家具 なども様変わりし、木材と比較して高発熱量の材料で構成された物 品が多くなっている。

その様な状況下で、施工技術や材料の開発も後押しし、土地の高 度利用等のために超高層化、大規模化した建築物が多く見られるよ うになった。特に超高層化、大規模化した建築物は、火災による潜 在的危険性が増大している可能性が指摘されている。それら建築物 の一室で火災が発生し、その室のガラス等の開口部材が熱破損し開
口から高温熱気流が噴出すれば、上方の開口部や外装材などを加熱 し、出火階以外の階へ延焼を引き起こす危険性がある ${ }^{677}$ 。建築物の 高層階で延焼が続けば、消防活動も極めて困難な状況になり、放任 火災の様相を呈する可能性もある。

開口から噴出する熱気流に関する研究は、従前から行われてきた が例えば 8) 15)、近年、よく見られるようになった開口形状が横方向に 連空した条件を想定した系統的な研究は稀である。横方向に長い開 口形状（以後、横長開口と寸る）から噴出した熱気流は、その気流 中心軸が壁面に沿う様にして上昇する傾向が把握されており、横長 開口による上階延焼の潜在的危険性が危惧される。さらに、前述し た通り、近年、外装材にサンドイッチパネルのような高性能な有機 系断熱材を使用する例も見られ、横長開口の上階延焼防止対策が課 題である。

現在、日本では、建築設計実務において、開口から噴出する熱気 流による上階延焼防止策を検討寸る場合、横井によって提案された 開口噴出熱気流性状予測手法 8)（以後、横井手法とする）が使用さ

\footnotetext{
* 東京理科大学理工学部建築学科 教授·博士 (工学)

** 韓国建設技術研究院 専任研究員 · 博士 (工学)

*** 国立研究開発法人建築研究所 研究員・博士 (工学)

**** 東京理科大学大学院国際火災科学研究科 大学院生
}

Prof., Dept. of Architecture, Faculty of Science and Technology, Tokyo University of Science, Dr.Eng: Research Specialist, Korea Institute of Civil Engineering and Building Technology, DrEng:

Researcher, Building Research Institute, Dr.Eng. Grad. Stud., Graduate School of Global Fire Science and Technology, Tokyo University of Science 
れることが多い。横井手法が提案された際、横井が実験で対象とし た開口形状のアスペクト比 $n(n=2 W / H, W$ :開口幅, $H$ :開口高さ $)$ は、 近年、建築物の設計事案で見られるような横長開口の形状を含まな い範囲で検討されている注1)。また、横井手法は、建築物内で燃焼 する可然物は木材を想定した什器などを想定しているため、建築物 に持ち込まれる可燃物の変化に伴い、火災室内で発生した可燃性ガ スのうち、未燃焼の状態で開口から噴出する可燃性ガス（以後、未 燃ガスとする）が増大寸る条件には、適用できない可能性が指摘さ れている16)。

そこで本研究では、横長開口を対象とし、可然物の条件が変化し た場合の横長開口から噴出する熱気流の性状に着目する。特に噴出 熱気流による上階延焼を検討する場合、噴出熱気流の温度分布や噴 出熱気流から壁面への入射熱流束などを把握することが肝要であり、 筆者らはそれらについて一連の研究を行っている。その中で、本報 では、横長開口の上方の温度分布性状に着目し、実大規模の燃焼チ ヤンバーを使用した実験結果を示す。実験は、横長開口（開口アス ペクト比 $\mathrm{n}$ が 5〜20の範囲）を対象とし、開ロアスペクト比 $\mathrm{n}$ を変 化させ、開口上端から上方の高さごとに最も高温となる鉛直壁面近 傍温度分布を中心に把握し、燃焼チャンバー内の可燃物が異なる場 合の温度分布性状一の影響も考慮した定量的な知見の収集を目的と した。更に、実験結果を考察し、横長開口から噴出する熱気流の鉛 直壁面近傍温度分布の簡便な算定モデルの提案を目的とした。

\section{2. 実験概要}

\section{1 実験装置}

実験は、東京理科大学火災科学研究センター実験棟で実施した。 図 1 は、本実験で使用した装置の概要図を示している。実験装置は、 火災室を想定した燃焼チャンバーと外壁を想定したファサードで構 成されている。燃焼チャンバーの寸法は幅 $4[\mathrm{~m}] \times$ 奥行 $4[\mathrm{~m}] \times$ 高さ $1.7[\mathrm{~m}]$ とし、燃焼チャンバーの周壁の材料構成は、鋼製アングルの 骨組みに、セラミックボード（厚さ: $100[\mathrm{~mm}]$ ）を固定させ、その 内壁面側にセラミックファイバーブランケット（厚さ：25[mm]） を張り合わせた。燃焼チャンバーには、開口部を 1 箇所、燃焼チャ ンバーの天井面から下方の $300[\mathrm{~mm}]$ 離れた高さに開口上端が位置 するよう設けた。開口面に設置したファサードは、高さ $5.7[\mathrm{~m}] \times$ 幅 $4[\mathrm{~m}]$ とし、鋼製アングルの骨組みに、けい酸カルシウム板（厚さ： $25[\mathrm{~mm}])$ を固定させ、加熱面側にセラミックファイバーブランケ ット（厚さ: $25[\mathrm{~mm}]$ ) を張り合わせた。火源は、可然物設置台（幅 $800[\mathrm{~mm}] \times$ 長さ $2400[\mathrm{~mm}])$ の短辺が開口と平行になるように設置 し、その上に可燃物として用いた液体燃料を注入した鋼製血（幅 $800[\mathrm{~mm}] \times$ 奥行 $800[\mathrm{~mm}] \times$ 深さ $100[\mathrm{~mm}])$ を 2 個設置した。

\section{2 測定の項目および方法}

実験で測定した項目および方法を以下に示す。実験計測は、デー タロガー(横河電機 MX100)を使用し、1 秒間隔で記録した。なお、 測定位置の概要は図 1 に示した通りである。

(1)重量減少速度

燃焼チャンバー内の液体燃料を注入した鋼製血を積載した可燃物 台を吊り上げたアングルを支えるようにロードセル(共和電業製： LUB-50KB, 定格容量 : $0.5[\mathrm{kN}])$ を燃焼チャンバーの天井上面に 3 基設置し、可燃物の重量を測定した。

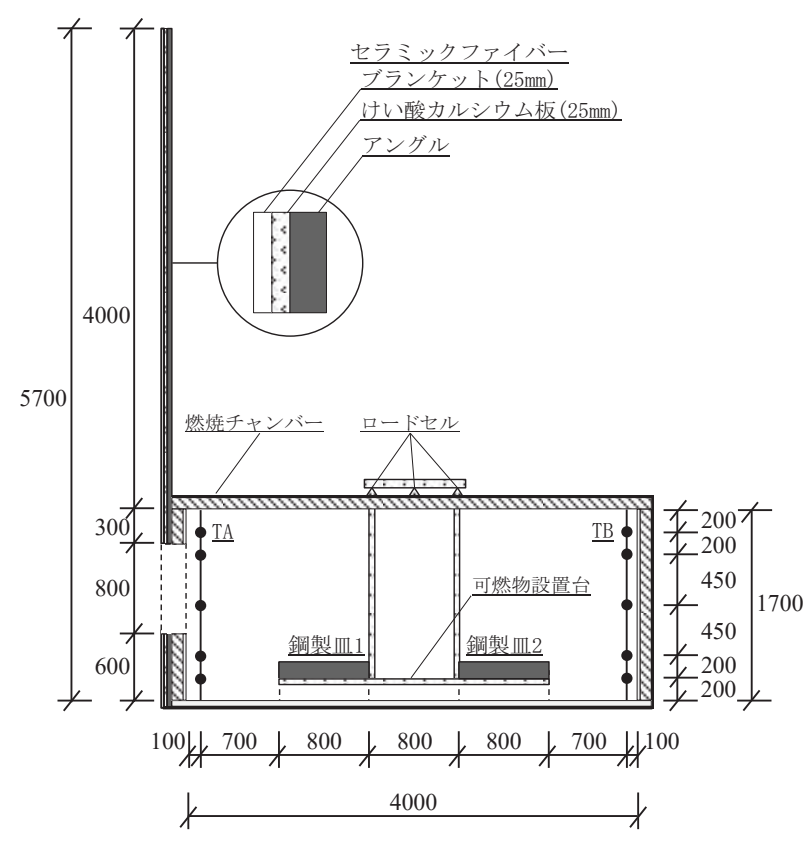

(a) 断面図

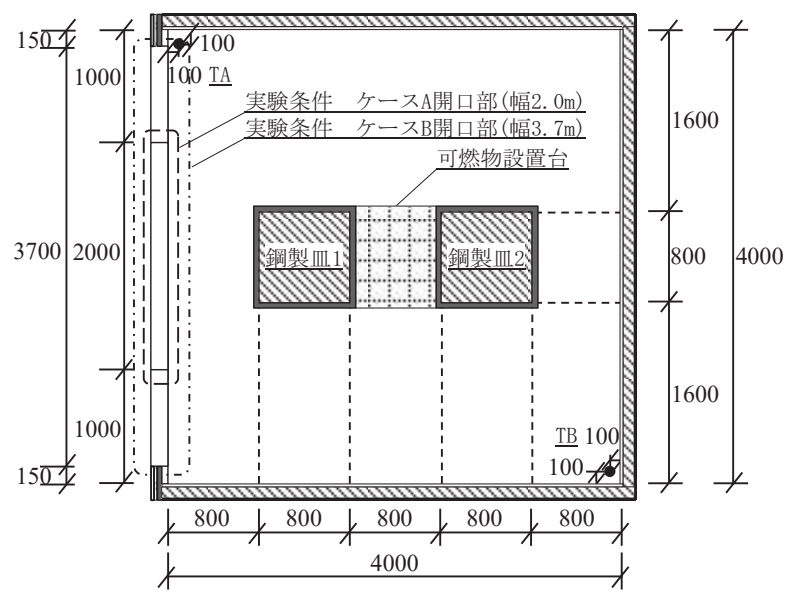

(b) 平面図

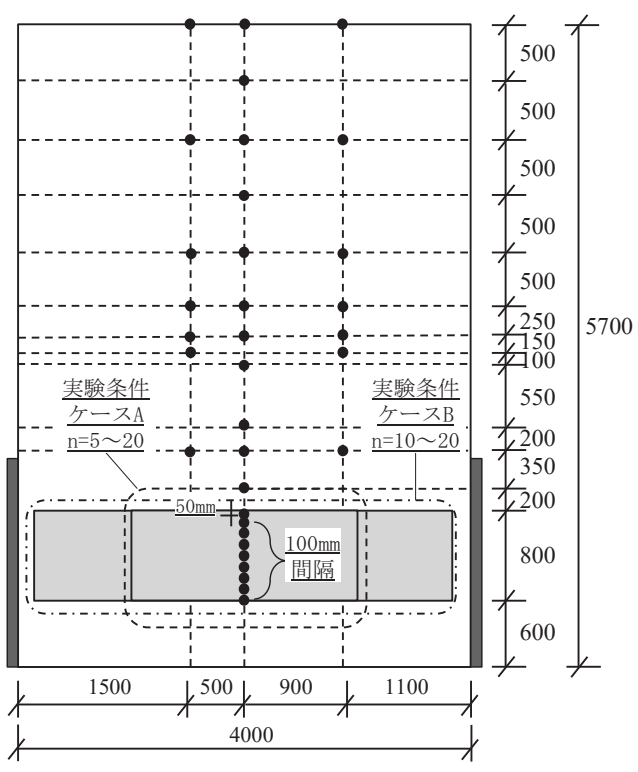

(c) 立面図

図 1 実験装置概要図 (単位: mm)
- 熱電対 
(2)温度

(1)燃焼チャンバー内

区画隅角付近の 2 箇所（TA および $\mathrm{TB}$ ）にシース熱電対（K 型 $\varphi 3.2[\mathrm{~mm}])$ を用いて、床面から鉛直方向に高さ $200[\mathrm{~mm}] 、 400[\mathrm{~mm}] 、$ $850[\mathrm{~mm}] 、 1300[\mathrm{~mm}] 、 1500[\mathrm{~mm}]$ の位置で温度を測定した。

(2)開口部

シース熱電対（K 型 $\varphi 3.2[\mathrm{~mm}]$ ）を用いて、開口上端から下方に 100[mm]までの範囲は 50[mm]間隔、100[mm]から開口下端までの 範囲は $100[\mathrm{~mm}]$ 間隔で温度を測定した。

(3)鉛直壁面近傍

図 1 (c) に示した位置にシース熱電対（K型 $\varphi 1.6[\mathrm{~mm}])$ を用い、 開口上端の鋁直壁面から $50[\mathrm{~mm}]$ 離れた位置の温度を測定した注 2$) 。$

\section{3 実験条件}

実験条件は、表 1 に示した通り、開口条件および可燃物条件を変 化させた。

開口条件は、開口幅 W $[\mathrm{m}]$ として $2[\mathrm{~m}] （$ ケース A）および $3.7[\mathrm{~m}]$ (ケース B ) の 2 条件を設定し、開口幅が $2[\mathrm{~m}]$ の場合には開口アス ペクト比 $\mathrm{n}$ が $\mathrm{n}=5 \sim 20$ の範囲で 6 条件、開口幅が $3.7[\mathrm{~m}]$ の場合には 開口アスペクト比 $n$ が $n=10 \sim 20$ の範囲で 3 条件となるよう開口高さ $H[\mathrm{~m}]$ を変化させた。

可燃物条件は、液体燃料のメタノール（燃焼熱 $19.8[\mathrm{MJ} / \mathrm{kg}]) 、 工$

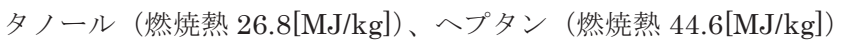
の 3 種類を使用し設定した ${ }^{17)}$ 。鋼製血に注入する液体燃料の量は、 可燃物の種類に関わらず $18[\mathrm{~L}]$ とした注 3$)^{2}$ 。なお、開口条件が幅 $2[\mathrm{~m}]$ ×高さ $0.2[\mathrm{~m}]$ 、可燃物条件がエタノールおよびヘプタンの実験では、 燃燒チャンバー内の可燃物の燃焼が不安定な状況が確認され、安全 のため実験を中止した。

表 1 実験条件

\begin{tabular}{|c|c|c|c|c|c|c|c|}
\hline & \multicolumn{4}{|c|}{ 開口条件 } & \multicolumn{3}{|c|}{ 可燃物条件 } \\
\hline & 幅 & 高さ & 換気因子 & アスペクト比 & \multirow{2}{*}{$\begin{array}{c}\text { メタノール } \\
\text { (18L) }\end{array}$} & \multirow{2}{*}{$\begin{array}{c}\text { エタノール } \\
(18 \mathrm{~L})\end{array}$} & \multirow{2}{*}{$\begin{array}{c}\text { ヘプタン } \\
\text { (18L) }\end{array}$} \\
\hline & $w$ & $\mathrm{H}$ & $A H^{1 / 2}$ & $n=W /(H / 2)$ & & & \\
\hline & [m] & {$[\mathrm{m}]$} & {$\left[\mathrm{m}^{5 / 2}\right]$} & {$[-]$} & \multirow{7}{*}{1.28} & 表面積 $\left[\mathrm{m}^{2}\right]$ & \\
\hline \multirow{6}{*}{ ケース A } & \multirow{6}{*}{2} & 0.8 & 1.43 & 5 & & & \\
\hline & & 0.6 & 0.93 & 6.7 & & & \\
\hline & & 0.5 & 0.71 & 8 & & & \\
\hline & & 0.4 & 0.51 & 10 & & & \\
\hline & & 0.3 & 0.33 & 13.3 & & & \\
\hline & & 0.2 & 0.18 & 20 & & & \\
\hline \multirow{3}{*}{ ケース B } & \multirow{3}{*}{3.7} & 0.74 & 2.36 & 10 & \multirow{3}{*}{\multicolumn{3}{|c|}{1.28}} \\
\hline & & 0.56 & 1.53 & 13.3 & & & \\
\hline & & 0.37 & 0.83 & 20 & & & \\
\hline
\end{tabular}

\section{3. 横長開口からの噴出熱気流温度に関するパラメータの整理}

自由空間中で可燃物の燃焼に伴い生じる上昇熱気流は、熱源の形 状がその性状に影響することが知られている例えば 18) 21)。それらの知 見を踏まえ、区画火災時に開口から噴出する熱気流の性状の解明が 行われ、開口アスペクト比 $\mathrm{n}$ が増加寸るに従い、開口噴出熱気流は、 開口から噴出した後、開口上方壁面に引き寄せられる傾向があり例え ば22）23）開口アスペクト比 n が 3.3 を超えるような条件では、熱気 流の中心軸は、概水開口上方の鉛直壁面に沿う傾向が報告されてい る ${ }^{24)}$ 。

横井により自由空間中の矩形熱源を想定し導出された無次元温度 を用い、開口噴出熱気流の温度分布の予測式が提案されているが 25)、 本研究の実験条件（開口アスペクト比 $n=5$ 以上）の範囲では開口噴
出熱気流の水平方向の断面形状が長方形熱源と同様の性状になると 仮定して、横長開口からの噴出熱気流温度に関するパラメータの整 理を行い、後述する実験結果および考察で引用する。

既往研究で示されているように例えば 8)、熱源上に形成される熱気 流は、浮力によって得られる運動エネルギーに基づき、熱源からの 高さ z[m]において

$\rho_{\mathrm{z}} \mathrm{W}_{\mathrm{z}}{ }^{2} \propto \Delta \rho \mathrm{gz}$

の関係式が成り立つ。ここで、 $\rho_{z}$ は高さ $z$ における熱気流密度 $\left[\mathrm{kg} / \mathrm{m}^{3}\right]$ 、 $W_{z}$ は高さ $z$ における速度 $[\mathrm{m} / \mathrm{s}] 、 \Delta \rho$ は密度差 $\left[\mathrm{kg} / \mathrm{m}^{3}\right] 、 \mathrm{~g}$ は重力加速 度 $\left[\mathrm{m} / \mathrm{s}^{2}\right]$ である。また、無限線熱源上の熱気流が持つ任意の高さ $z$ における熱量は、

$Q_{I, D} \propto C_{p} \Delta T_{2} \rho_{2} A_{2} W_{2}$

で表される。ここで、 $Q_{I, D}$ は単位長さ当たりの発熱速度 $[\mathrm{kW} / \mathrm{m}] 、 c_{p}$ は比熱 $[\mathrm{kJ} / \mathrm{kgK}] 、 \Delta \mathrm{T}_{2}$ は熱気流と雰囲気の温度差 $[K] 、 A_{z}$ は熱気流水 平断面長さ $[\mathrm{m}]$ である。

故に、式(1)、式(2)、および $\rho \top \approx$ const とすれば

$\left(\frac{\Delta T_{z}}{T_{\infty}}\right)^{3 / 2} \propto \frac{Q_{1, D}}{C_{p} T_{\infty} \rho_{z} A_{z} g^{1 / 2} z^{1 / 2}}$

の関係式が得られる。ここで $A_{z}$ は、

$A_{z} \propto Z$

となり、式(3)に式(4)を代入し整理すると

$\frac{\Delta T_{z}}{T_{\infty}} \propto\left(\frac{Q_{1, D}}{c_{p} T_{\infty} \rho_{z} g^{1 / 2} z^{3 / 2}}\right)^{2 / 3}$

となる。

従って、左辺を $\Delta \mathrm{T}_{2}$ で整理すると式(6)が得られる注4)。

$\Delta T_{z} \propto\left(\frac{T_{\infty} Q_{1, D}{ }^{2}}{C_{p}{ }^{2} \rho_{z}^{2} g}\right)^{1 / 3} z^{-1}$

無限線熱源のモデル式(6)を長方形熱源に拡張し、熱源の代表寸法 を $\mathrm{D}[\mathrm{m}]$ とすると

$\frac{\Delta T_{z} D}{\left(\frac{T_{\infty} Q_{I, D}^{2}}{C_{p}^{2} \rho_{z}^{2} g}\right)^{1 / 3}} \propto\left(\frac{z}{D}\right)^{-1}$

となり、この式の両辺は無次元数となる。ここで、式(7)の左辺を無 次元温度 $\Theta_{D, z}[-$ - と置く注 5)。

$\Theta_{D, z}=\frac{\Delta T_{z} D}{\left(\frac{T_{\infty} Q_{I, D}^{2}}{C_{P}^{2} \rho_{z}^{2} g}\right)^{1 / 3}}$

更に、長方形熱源の無次元発熱速度 $Q^{*}{ }_{1, D}[$ - ]

$Q_{1, D}^{*}=\frac{Q_{1, D}}{\rho_{\infty} C_{p} T_{\infty} \sqrt{g} D^{3 / 2}}$

と定義すると、式(8)は 
$\Theta_{D, z}=\frac{1}{Q_{1, D}^{* 2 / 3}} \cdot \frac{\Delta T_{z}}{\left(T_{\infty} \cdot T_{z}^{2}\right)^{1 / 3}}$

と表すことができる ${ }^{10)}$ 。なお、 $\mathrm{T}_{2}$ は高さ $\mathrm{z}$ における熱気流温度 $[\mathrm{K}]$ である。

本研究では、開口アスペクト比 $\mathrm{n}$ が大きい横長開口から噴出する 熱気流の熱源は、図 2 のように開口から噴出した直後から壁に沿い ながら熱気流が上昇し、壁際に長方形熱源（長辺：W $[\mathrm{m}]$ 、短辺： $D / 2[\mathrm{~m}]$ 、発熱量 : $\left.Q_{I, D} / 2[\mathrm{~kW} / \mathrm{m}]\right)$ が位置すると仮定し、自由空間中 の長方形熱源（長編 : W $[\mathrm{m}]$ 、短辺 : D $[\mathrm{m}]$ 、発熱量 : $Q_{I, D}[\mathrm{~kW} / \mathrm{m}]$ ) に置き変える ${ }^{27)}$ 。ここでは、熱気流の失熱や空気巻き込み等に対す る開口部上方の壁の影響は無視する。

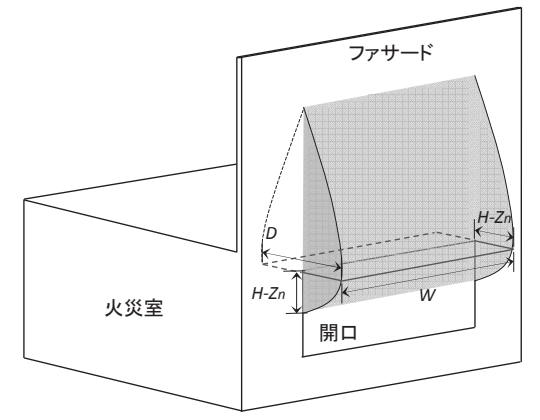

図 2 横長開口から噴出する熱気流の概念図

ここで、開口部における噴出熱気流の中性帯高さ $\mathrm{Zn}[\mathrm{m}]$ を用い、 長方形熱源の短辺を $\left(H-Z_{n}\right)[\mathrm{m}]$ 、発熱量を $Q_{1,(H-Z n)}[\mathrm{kW} / \mathrm{m}]$ と置き、無 次元発熱速度 $Q^{*}{ }_{1,(H-Z n)}\left[-\right.$ - ]および無次元温度 $\Theta_{(H-Z n)}[-]$ を

$Q_{1,(H-Z n)}^{*}=\frac{Q_{1,(H-Z n)}}{\rho_{\infty} C_{p} T_{\infty} \sqrt{g}\left(H-Z_{n}\right)^{3 / 2}}$

$\Theta_{(H-Z n)}=\frac{1}{Q_{1,(H-Z n)}^{*}{ }^{2 / 3}} \cdot \frac{\Delta T_{Z}}{\left(T_{\infty} \cdot T_{Z}^{2}\right)^{1 / 3}}$

と書き換え定義する。また、開口から噴出する単位長さ当たりの熱

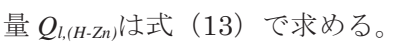

$Q_{1,(H-Z n)}=\left\{c_{p} R_{f_{0}}\left(T_{f}-T_{\infty}\right)\right\} / W$

ここで、 $R_{f o}$ は式(14)で求めた噴出熱気流流量 $[\mathrm{kg} / \mathrm{s}] 、 T_{\mathrm{f}}$ は噴出熱気流 温度 $[\mathrm{K}]$ 、式(14)中の $\rho_{\mathrm{f}}$ は燃焼チャンバー内気体密度 $\left[\mathrm{kg} / \mathrm{m}^{3}\right]$ である 15)。

$\mathrm{R}_{\mathrm{fo}}=\frac{2}{3} \alpha \mathrm{W} \sqrt{2 \mathrm{~g} \rho_{\mathrm{f}}\left(\rho_{\infty}-\rho_{\mathrm{f}}\right)}\left(\mathrm{H}-\mathrm{Z}_{\mathrm{n}}\right)^{3 / 2}$

なお、式(12)の右辺中の温度を表すパラメータをまとめた無次元 温度 $T^{*}[-]$ 一

$T^{*}=\frac{\Delta T_{z}}{\left(T_{\infty} \cdot T_{z}^{2}\right)^{1 / 3}}=\frac{\Delta T_{z} / T_{\infty}}{\left(\Delta T_{z} / T_{\infty}+1\right)^{2 / 3}}$

と定義し、本報では取り扱う。注6)

\section{4. 実験結果および考察}

\section{1 開口から噴出する火炎の発生有無}

開口から噴出する火炎（以後、噴出火炎とする）の発生有無につ いて、目視観察から得られた結果を整理する。可燃物条件としてメ タノールを使用した場合、幅 $3.7[\mathrm{~m}] \times$ 高さ $0.74[\mathrm{~m}]$ 、幅 $3.7[\mathrm{~m}] \times$ 高
さ $0.56[\mathrm{~m}]$ 、幅 $2[\mathrm{~m}] \times$ 高さ $0.8[\mathrm{~m}]$ の開口条件では、噴出火炎の発生 は確認されなかったが、それら以外の条件では、噴出火炎の発生が 確認された。噴出火炎の発生が確認されなかった条件では、液体燃 料を注入した鋼製皿の上方に火炎が形成されたが、天井に衝突した 火炎の天井面下における展炎範囲は限定的であり、開口まで火炎は 到達しないことを確認した。目視観察の結果から噴出火炎の発生が 確認されなかった条件の可燃物の燃焼状態は、可燃物条件に依存す る、いわゆる燃料支配型であったと考えられる。

以上の結果を踏まえ、噴出火炎の発生有無と可燃物の発熱速度お よび温度との関係を整理する。なお、以後、整理した実験結果は、 計測したデータのピーク值を示した時間の前後 10 秒の平均值を代 表值として採用している。

(1)発熱速度との関係

図 3 は、縦軸にロードセルで測定した重量減少速度の代表値に燃 料の燃焼熱を乗じ算出した発熱速度 $Q_{c}[\mathrm{~kW}]$ を式(16)の計算值 $Q_{v, \text { max }}[\mathrm{kW}]$ で除した值、横軸に燃焼チャンバーの周壁面積 $\mathrm{A}_{T}\left[\mathrm{~m}^{2}\right]$ を 開口因子 $\mathrm{AH}^{1 / 2}\left[\mathrm{~m}^{5 / 2}\right]$ で除した值をとり整理した結果である ${ }^{16)}$ 。こ で $Q_{v, \text { max }}$ は、開口からの流入空気量 $R_{\mathrm{fo}}$ を $0.5 \mathrm{AH}^{1 / 2}[\mathrm{~kg} / \mathrm{s}]$ で概算し注 7)、 その值に単位酸素量当たりの燃焼熱 $\Delta \mathrm{H}_{\mathrm{air}}(\approx 3000[\mathrm{~kJ} / \mathrm{kg}])$ を乗じ算 出した発熱速度の概算值を示している。すなわち、図 3 の縦軸の值 が 1 を超える条件では、開口からの流入空気量が燃焼チャンバー内 で発生した可然性ガスを全て燃焼させるための必要量に満たないた め、未燃ガスが開口から噴出すると考えられる。

$Q_{v, \max }=\Delta H_{\text {air }} R_{f 0}=1500 A \sqrt{H}$

図 3 より、本実験条件の範囲では、可燃物および開口幅が同条件 ごとに見れば、横軸の值が増加するにつれ、縦軸の值も増加する傾 向が見られる。また、縦軸の值が 1 を超える全ての条件で噴出火炎 は発生していることがわかる。なお、縦軸の值が 1 以下の条件でも 噴出火炎が発生する条件が見られる。そこで既往研究で示された噴 出火炎の発生限界を示寸発熱速度の算定式(17)を用い、式(17)を式 (16)で除し求めた式(18)を図中に実線で示す 16)。

$Q_{\mathrm{v}, \text { crit }}=150 \mathrm{~A}_{\mathrm{T}}^{2 / 5} \cdot(\mathrm{A} \sqrt{\mathrm{H}})^{3 / 5}$

$Q_{v, \text { crit }} / Q_{v, \text { max }}=0.1\left(A_{T} / A \sqrt{H}\right)^{2 / 5}$

図 3 から図中の式(18)を表す直線より上方に実験值がプロットさ れる条件では噴出火炎が発生し、下方の值は噴出火炎が発生しない 傾向が見られる。すなわち本実験条件の範囲では、式(18)は噴出火 炎の発生有無を判断する上で矛盾がない結果となった。

(2)温度との関係

図 4(a)は、縦軸に開口部の中性帯より上方の平均温度、図 4(b)は、 縦軸に燃燒チャンバー内の平均温度をとり、それぞれの横軸に燃焼 チャンバーの周壁面積 $\mathrm{A}_{\mathrm{T}}\left[\mathrm{m}^{2}\right]$ を開口因子 $\mathrm{AH}^{1 / 2}\left[\mathrm{~m}^{5 / 2}\right]$ で除した值をと り、整理した結果である。

図 4(a) と(b)を比較した結果、同じ実験条件では、全体的に燃焼チ ヤンバー内の温度は開口部の温度より幾分高い值を示す傾向が見ら れる。また、図 4(a)、(b) ともに、噴出火炎が発生する条件では、可 燃物および開口幅が同条件ごとに見れば、横軸の值が増加するに従 い、温度は徐々に低下寸る傾向が見られる。これは横軸の值の増加 
は、開口因子 $A H^{1 / 2}$ の值が減少し開口からの流入空気量が減少する ことを意味し、燃焼チャンバー内の可然性ガスの発熱量が低減する ためと考えられる。なお、噴出火炎が発生しない条件は、温度が十 分に上昇せず、噴出火炎が発生する条件より低くなる傾向を示して いる。

\section{2 鉛直壁面近傍温度分布}

図 5 は、縦軸に鈆直壁面近傍温度 $\Delta \mathrm{T}[\mathrm{K}]$ 、横軸に開口上端から壁 際に沿った鉛直高さ z $[\mathrm{m}]$ をとり、液体燃料の種類ごとに分け、鉛直 壁面近傍温度分布を整理した結果である。なお以降、目視観察の結 果、噴出火炎が発生した条件を対象とし整理する。

図 5 から、高さ z の值が増加するに従い、液体燃料がメタノール の条件では温度は徐々に減衰し、エタノール、ヘプタンの条件では 開口上端付近の温度減衰の傾向は顕著ではないが、 $z$ が $1[\mathrm{~m}]$ の付近 から温度減衰は顕著となり、徐々に - 1 乗の温度減衰の勾配に近づ く傾向が見られる。自由空間中の長方形熱源は、火炎片高さより上 方の温度分布が熱源からの鉛直高さに対し、徐々に- 1 乗の温度減 衰に近づくことから、横長開口から噴出する熱気流の鉛直壁面近傍 温度の温度減衰は、自由空間中の長方形熱源と同様の傾向を示寸結 果となった ${ }^{28)}$ 。図 $5(\mathrm{a}) \sim(\mathrm{c})$ の結果を比較すると、開口条件が同じ場 合、燃焼熱が高い液体燃料ほど、横軸の z に対し温度は高い值を示 寸傾向が見られる。

図 6 は、3 節で導出したパラメータに基づき、縦軸に T* ${ }^{*}$ - ] 横 軸に $Q^{*}{ }_{1,(H-Z n)}^{-2 / 3} \mathrm{Z}_{(\mathrm{H}-Z \mathrm{Zn})}^{*}[-$ - ]をとり、鉛直壁面近傍無次元温度分布を整
理した結果である。なお、ここで無次元長さ $z_{(H-Z n)}^{*}[-]$ は、

$Z_{(H-Z n)}^{*}=\frac{Z}{H-Z_{n}}$

と定義する。また、図 6 中の実線は、自由空間中の長方形熱源上の 温度分布を示寸既往の式(20)から導出した ${ }^{28}$ 。式(20)に示した通り、 長方形熱源上の温度分布は、無次元長さ $z^{*}$ 。により判別し計算式が 示されている。

$\Delta T=\left\{\begin{array}{cc}900 & \left(z_{D}^{*} \leq 1.4\right) \\ k / z_{D}^{*} & \left(1.4<z_{D}^{*}\right)\end{array}\right.$

ここで、係数 $k=1260$ 、無次元長さ $z^{*}{ }_{D}[-]$ は

$Z_{D}^{*}=Z /\left(D \cdot Q_{1, D}^{* 2 / 3}\right)$

である。図 6 の T*および $\mathrm{Q}^{*}{ }_{\mathrm{I},(\mathrm{H}-\mathrm{Zn})}{ }^{-2 / 3} \mathrm{Z}_{(\mathrm{H}-\mathrm{Zn})}^{*}$ の軸に合わせ、式(20)を 書き換えると式(22)が得られる。

$\mathrm{T}^{*}=\frac{\psi}{(\psi+1)^{2 / 3}}$

ここで

$\psi=\left\{\begin{array}{cc}900 / \mathrm{T}_{\infty} & (\mathrm{x} \leq 0.88) \\ 794 /\left(\mathrm{xT}_{\infty}\right) & (0.88<\mathrm{x})\end{array}\right.$

$X=Q_{1,(H-Z n)}^{*-2 / 3} \cdot Z_{(H-Z n)}^{*}$

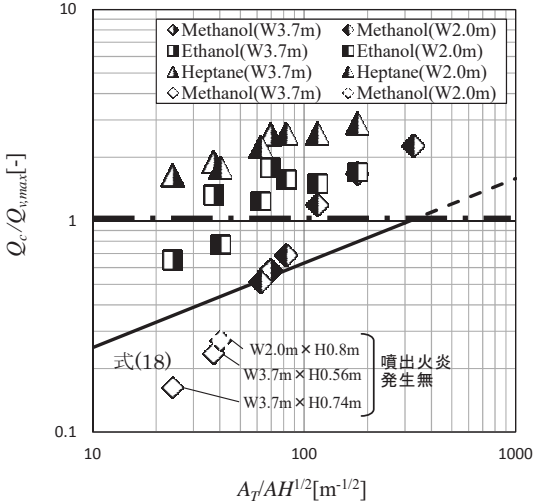

図 3 発熱速度

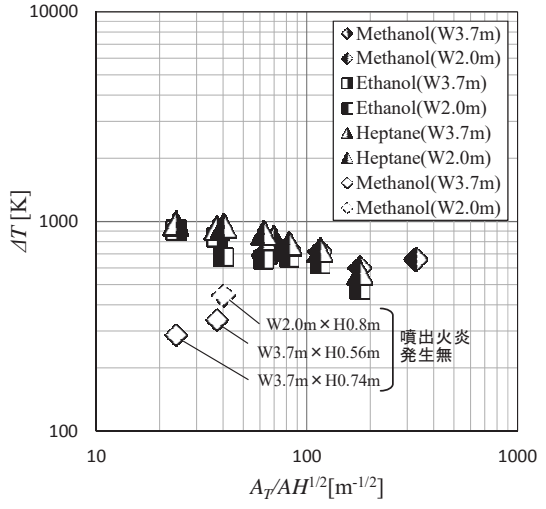

(a) 開口部

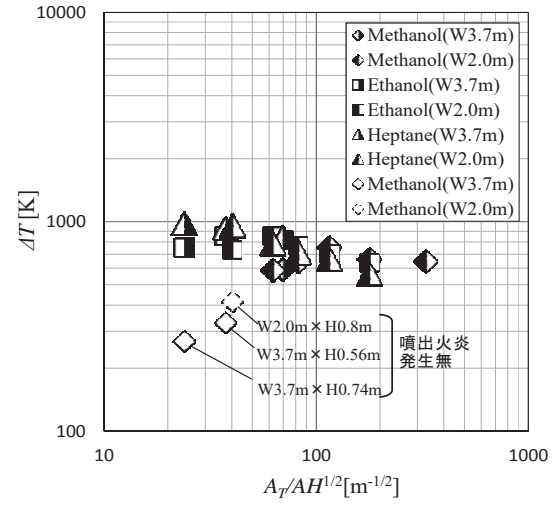

(b) 燃焼チャンバー内

図 4 温度

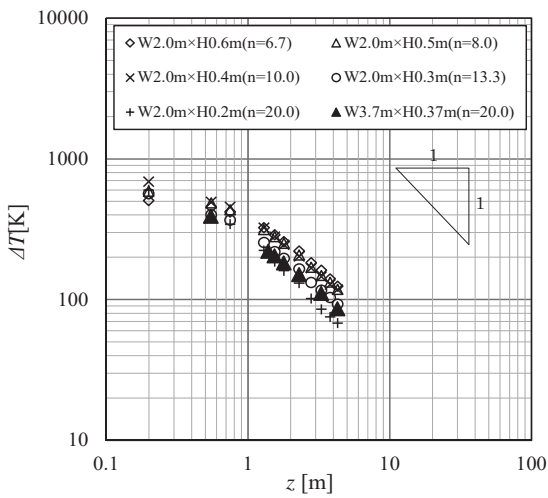

(a)メタノール

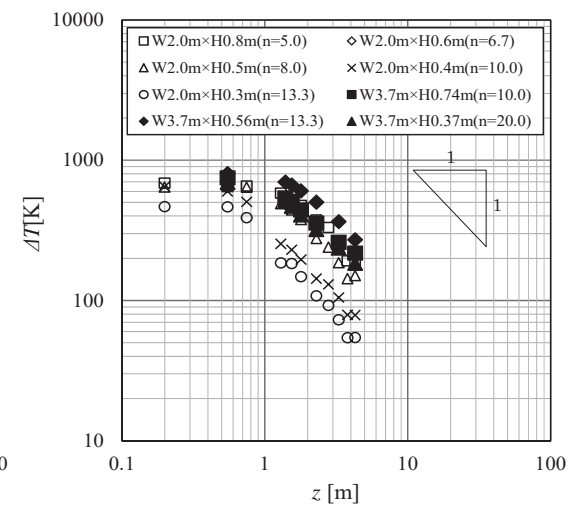

(b) エタノール

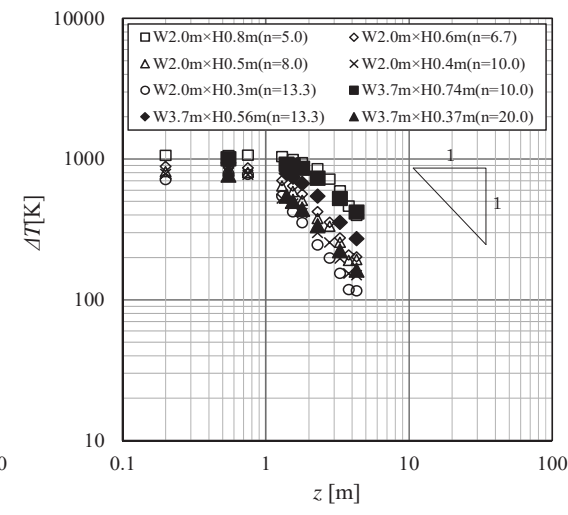

(c)ヘプタン

図 5 鉛直壁面近傍温度分布 
である注8)。因みに式(20)の係数 k は、熱源から近距離の温度減衰分 布に基づき、熱源からの鉛直高さに対し - 1 乗で温度減衰すると仮 定し導出している ${ }^{28)}$ 。

図 6 より、実験条件ごとの無次元温度 T*は、式(22)を示す実線と 比較した場合、横軸の無次元值が 1.0 を超えた付近から、横軸の值 に対しプロットが実線から離れ、高い值を示寸傾向が見られる。ま た、プロットと式(22)を示す実線の差は、燃焼熱が高い液体燃料ほ ど、広がる傾向が見られる。

\section{3 無次元温度の補正}

(1)噴出熱気流熱量の検討

図 6 の無次元温度と式(22) を示す実線の差が生じる要因につい て、3 節で示したパラメータを対象に検討する。ここでは、図 6 の 結果から、液体燃料の差異による温度差が顕著であることなどを踏 まえると噴出熱気流の熱量を過少に評価している可能性があること

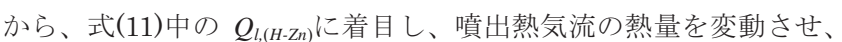
無次元温度の補正を試みる。補正方法として補正值 $Q_{\text {ef }}[\mathrm{kW}$ を用い、 式(13)を式(25)に置き換える。

$Q_{1,(H-Z n)}=\left\{c_{p} R_{f o}\left(T_{f}-T_{\infty}\right)+Q_{\text {ef }}\right\} / W$

図 6 の実線上に条件ごとの無次元温度分布が一致するよう、式 (25)の $Q_{\text {ef }}$ の值を変化させた結果が図 7 である注9)。図 7 より $Q_{\mathrm{ef}}$ の 值を変化させることにより、式(22)を示寸実線と大差なく一致する
よう鉛直壁面近傍無次元温度分布を整理できることがわかる。この 結果は、噴出熱気流の保有する熱量を適切に評価できれば、式(22) を用い横長開口から噴出する熱気流の温度分布に近似した結果が簡 便に算定できることを示唆している。因夕に、式(23)の $x \leqq 0.88$ の 条件で求められる $\mathrm{T}^{*}$ の計算值は、長方形熱源上の近傍温度に基づい ているが、燃焼チャンバー内の上昇温度 $\Delta T_{\mathrm{f}}[\mathrm{K}]$ を用いれば、式(23) は式(26)となる。

$\psi=\left\{\begin{array}{cc}\Delta \mathrm{T}_{\mathrm{f}} / \mathrm{T}_{\infty} & \left(\mathrm{x} \leq 794 / \Delta \mathrm{T}_{\mathrm{f}}\right) \\ 794 /\left(\mathrm{xT}_{\infty}\right) & \left(794 / \Delta \mathrm{T}_{\mathrm{f}}<\mathrm{x}\right)\end{array}\right.$

図 7 中の 2 本の一点鎖線は、液体燃料の種類ごとに式(26)から求 めた開口付近の T*の最小值と最大值の範囲を示しているが、開口付 近の $T^{*}$ の実験值はその範囲に位置する傾向が見られる注 10$) 。$

(2)補正值に関する考察

式(25)で用いた $Q_{\text {ef }}$ 、巨視的に見れば、開口から噴出する未燃ガ スの発熱量と関係することが考えられる。そこで、図 7 から得られ

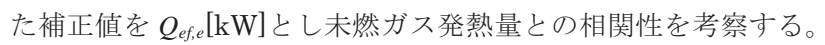

火災室内で燃焼する可燃性ガスの発熱量は式(16)および式(17)か ら求めた值とする。未燃ガス発熱量は、火災室内で発生した可燃性 ガスが全て燃焼すると仮定した発熱量 $Q_{c}[\mathrm{~kW}$ 品ら式(16)および式 (17)の算定值を差し引いた式(27)および式(28)で算出し、それぞれ $Q_{\text {ef,max }}[\mathrm{kW}]$ おひび $Q_{\text {ef,crit }}[\mathrm{kW}]$ と定義する。それら算定值と $Q_{\text {ef,e }}$ の関係 を整理する。

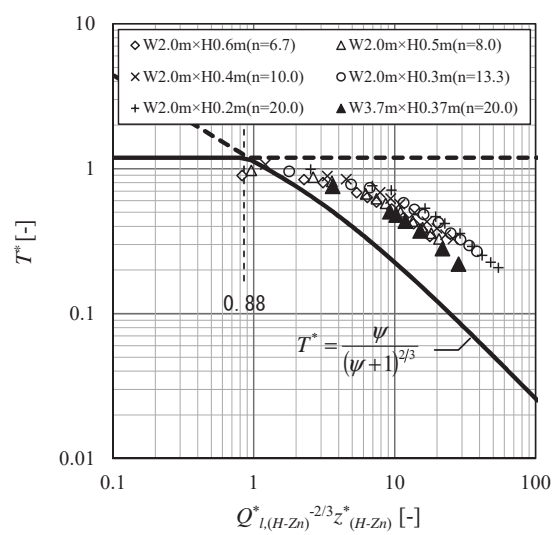

(a)メタノール

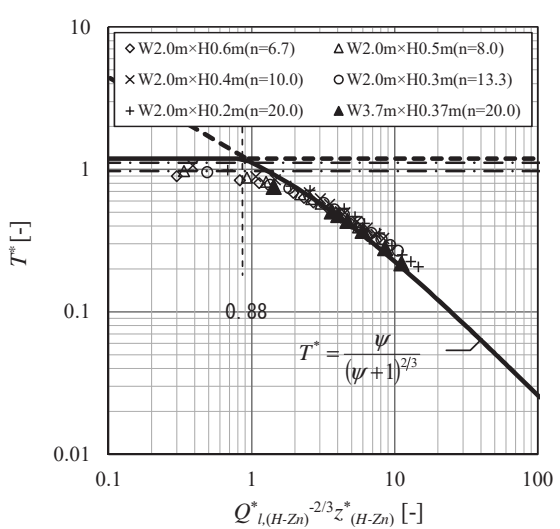

(a)メタノール

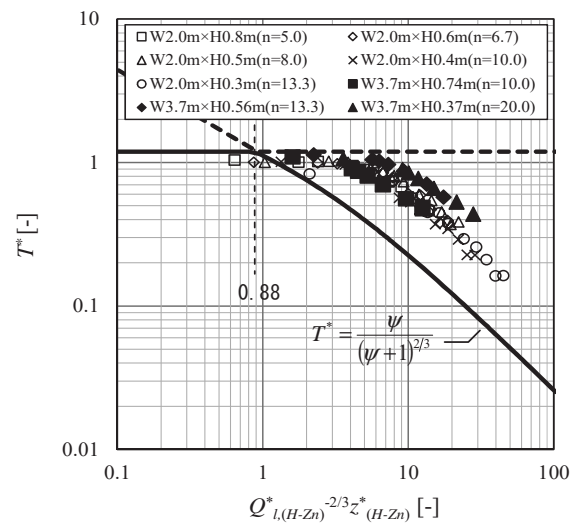

(b) エタノール

図 6 鉛直壁面近傍無次元温度分布

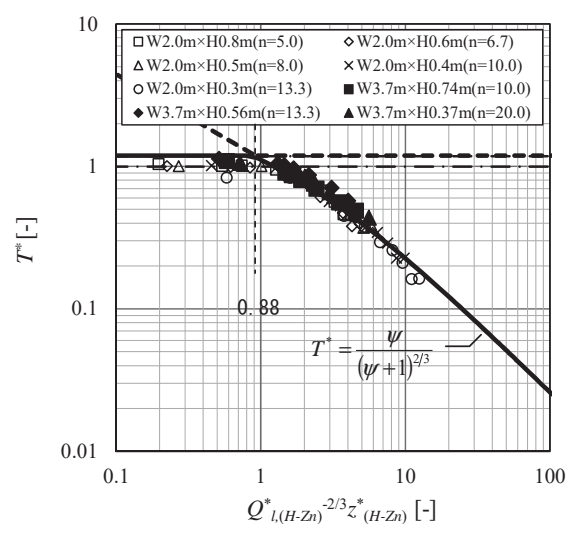

(b) エタノール

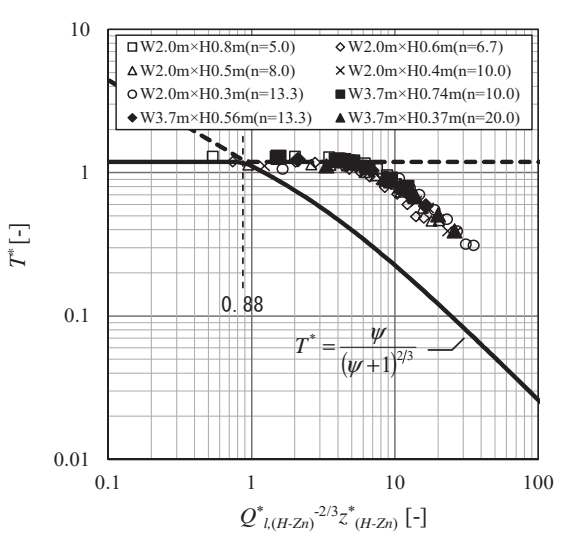

(c)ヘプタン

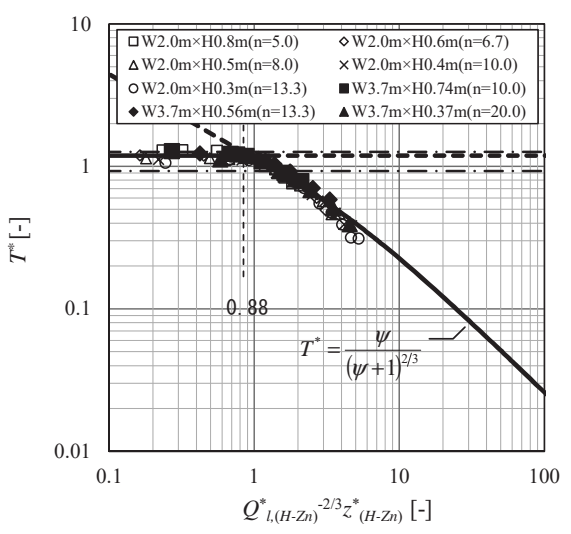

(c)ヘプタン

図 7 補正値 $Q_{e f}$ を用いた鉛直壁面近傍無次元温度分布 
$Q_{\mathrm{ef}, \max }=Q_{c}-Q_{v, \text { max }}=Q_{c}-1500 A \sqrt{H}$

$Q_{\text {ef }, \text { crit }}=Q_{c}-Q_{v, c r i t}=Q_{c}-150 A_{T}^{2 / 5} \cdot(A \sqrt{H})^{3 / 5}$

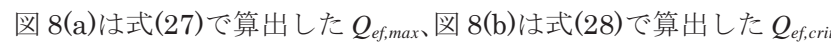
を縦軸にとり、それぞれの横軸に $\mathrm{Q}_{\mathrm{efe}, \mathrm{e}}$ をとり、整理した結果である。 なお、図 8(a)において、式(27)の算定值がマイナスの值を示す条件 のプロットは、縦軸の值が $Q_{\text {ef, } \max }=1$ となる線上にプロットしており、 式(27)の算定值と整合していない。

図 8(a)より、式(27) の算定值 $Q_{e f, \max }$ は全体的に $Q_{e f, e}$ と比べ低い值 を示寸傾向が見られる。開口から噴出する未燃ガスが燃焼し噴出火 炎が形成されると考えれば、式(27)の算定值がマイナスの条件では、 未燃ガスが生じないため噴出火炎が形成されないことになり、未燃 ガス発熱量が適切に評価されていないことになる。一方、図 8(b)よ り、式(28)の算定值 $Q_{\text {ef,crit }}$ は、可燃物としてメタノールを使用した場 合、開口因子 $\mathrm{AH}^{1 / 2}$ の值が大きい条件で過少評価する傾向は見られ るものの、式(27) の算定值と比べ、全体的に $Q_{\text {ef,crit }}$ と $Q_{\text {ef,e }}$ が同值を 示す実線の付近に算定值がプロットされる傾向が見られる。

\section{4 鉛直壁面近傍温度分布の簡便な近似モデル}

本実験条件の範囲で得られた結果および考察に基づき、横長開口 から噴出する熱気流の鉛直壁面近傍温度分布の簡便な近似モデルに ついて整理する。まず、横長開口からの噴出熱気流の鉛直壁面近傍 温度は、自由空間中の長方形熱源の提案式を拡張した式(22)から簡

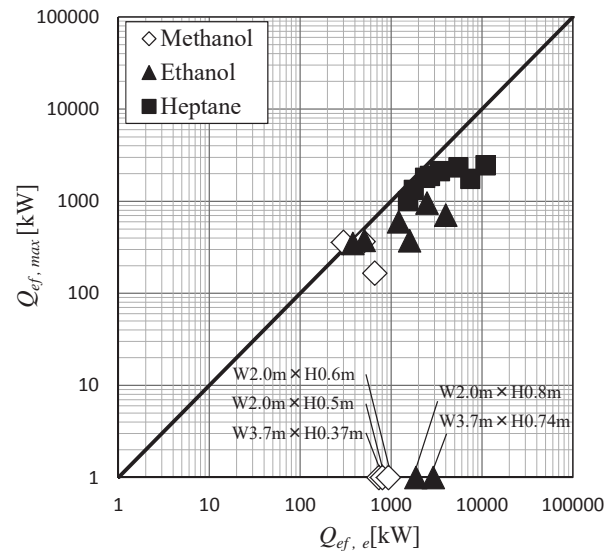

(a) $Q_{\text {ef, } \max }$

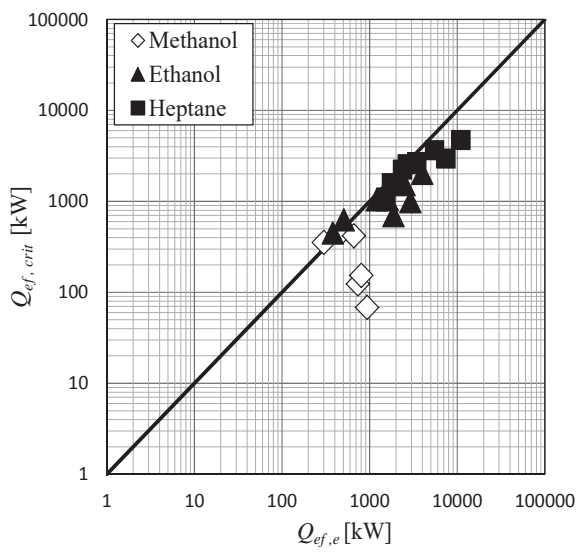

(b) $Q_{\text {ef,crit }}$

図 8 補正値と未燃ガス発熱量
便に算定することができる。また、式(22)中の噴出熱気流熱量は、 本実験条件の範囲では、式(28)を用い算出した発熱量 $Q_{\text {ef,crit }}$ を補正值 として用いることにより、実験で得られた鉛直壁面近傍温度分布に 近似した結果が得られる。

なお本報では、噴出熱気流熱量の算定に対し、噴出熱気流のエン タルピー量の他に未燃ガスの発熱量の影響が卓越していると考え、 熱気流の失熱や空気巻き込久等に対する開口上方の壁の影響等は考 慮していないが、より精緻なモデルの構築を行う際には、未燃ガス 発熱量の予測を含めたそれらの検討が必要である。また、開口付近 の温度を適切に予測するためには、区画内火災温度等を考慮した T* の算定方法が必要であり、今後、検討を進めていく。

\section{5. まとめ}

本研究では、横長開口から噴出寸る熱気流の温度分布性状につい て、実大規模の区画を使用した実験を実施し、区画内の可燃物が異 なる場合の温度分布性状一の影響を考慮した定量的な知見の収集を 行い、更に、横長開口から噴出寸る熱気流の鉛直壁面近傍温度分布 の簡便な算定モデルを提案した。

本実験条件の範囲で、本研究から得られた主な知見を以下に示す。

(1) 噴出火炎の発生有無

- 開口から噴出する火炎の発生有無について目視観察した結果、本 実験条件の範囲では、 $Q_{d} / Q_{v, \max }$ が 1 を超える全ての条件で噴出火炎 は発生した。

・式(18)の算定值 $Q_{v, c r i t} / Q_{v, \text { max }}$ は噴出火炎の発生有無を判断する上で 矛盾がない結果となった。

(2) 鉛直壁面近傍温度分布

・鉛直壁面近傍温度は、開口上端から壁際に沿った鉛直長さ $z$ が増 加するにつれ、徐々に - 1 乗の温度減衰の勾配に近づく傾向が見ら れた。

・鉛直壁面近傍無次元温度分布は、補正値 $Q_{\text {ef }}$ を用いることにより 式(22)を示す実線と大差なく一致するよう整理できる。

・式(27)の算定值 $Q_{\text {ef, } \max }$ と比較して、式(28)を用いた算定值 $Q_{\text {ef, crit }}$ の 方が、実験から求めた補正值 $Q_{\mathrm{ef}, \mathrm{e}}$ と近い值を示寸傾向が見られた。

(3) 横長開口からの噴出熱気流の鉛直壁面近傍温度分布の簡便な近 似モデル

- 横長開口からの噴出熱気流の鉛直壁面近傍温度分布は、式(22)か ら簡便に求められ、式(22)中の噴出熱気流熱量は、式(28)を用い算 出した值 $Q_{\text {eff,crit }}$ 用いることにより、実験で得られた鉛直壁面近傍 温度分布に近似した結果が得られる。

\section{謝辞}

本研究を進めるにあたり、元東京理科大学大学院生の稲田祥之氏、 外山敬寛氏に多大なるご協力を得ました。また、本稿の作成にあた り、大林組技術研究所の山口純一氏、大成建設技術センターの中村 正寿氏に貴重なご助言を頂きました。ここに記して謝意を表します。

注

注1）横井は、横に長い開口形状としてアスペクト比 $\mathrm{n}=6.4$ までを対象と している。

注2）本実験装置を用い、予備実験としてファサード表面から $200[\mathrm{~mm}]$ 程 度離れた位置まで垂直方向に $10[\mathrm{~mm}]$ 間隔で最高温度を示す位置を 
確認し、ファサード表面から $50[\mathrm{~mm}]$ の位置の温度を代表温度とし て用いることとした。

注3）実験室の安全性の観点から、予備実験を実施し、火炎形状が概ね安 定する可燃物量として 18[L]を上限とした。また、可然物としてへプ タンを使用する場合、実験装置周囲への火炎からの放射熱等が大き く、燃焼チャンバー両端付近に養生用のボードを配置した。

注4） $\rho_{\mathrm{z}}=\rho_{\infty}$ と仮定すれば、無限線熱源上に形成される熱気流の上昇温度は、 Z に反比例することになる。すなわち、熱源から離れ熱気流の温度が 低下寸るにつれ、その傾向は顕著に見られるようになる。

注5）横井手法で定義された無次元温度は、分母の発熱量 $[\mathrm{kW}$ の単位を持 つパラメータは単位長さ当たりの值ではないため、分子の長さ $[\mathrm{m}]$ の単位を持つパラメータの次数が $5 / 3$ で表されている。

注6）無次元温度 $T^{*}$ は、開口上端から壁際に鉛直方向に採った高さ $\mathrm{z}$ を開 口高さHから中性带高さ $\mathrm{Zn}$ を差し引いた值 $(\mathrm{H}-\mathrm{Zn})$ で除した無次元長 さに対応する。

注7）開口からの流入空気量 $\mathrm{R}_{\mathrm{fo}}$ は、燃焼チャンバー内の可燃性ガスの発生 量を考慮すると $0.5 \mathrm{AH}^{1 / 2}$ より若干少なくなることが考えられるが簡 便さを考慮し $0.5 \mathrm{AH}^{1 / 2}$ で概算することとした。

注8）雰囲気温度 $T_{\infty}$ は $293[\mathrm{~K}]$ を用いた。また、式(20)の $1.4<z_{D}^{*}$ の条件で、 式 $(20)$ のパラメータに $D=2\left(H-Z_{n}\right) 、 Q_{I, D}=2 Q_{I,(H-Z n)}$ を代入すると

$$
\Delta \mathrm{T}=\frac{1260}{\mathrm{Z} /\left(\mathrm{D} \cdot \mathrm{Q}_{\mathrm{D}}^{* 2 / 3}\right)}
$$$$
\approx \frac{1260}{\mathrm{Z} /\left(\left(\mathrm{H}-\mathrm{Z}_{\mathrm{n}}\right) \cdot \mathrm{Q}_{\mathrm{I},(\mathrm{H}-\mathrm{Zn})}^{*}{ }^{2 / 3}\right)} \times \frac{1}{1.59}
$$

$$
\approx \frac{794}{\mathrm{z} /\left(\left(\mathrm{H}-\mathrm{Z}_{\mathrm{n}}\right) \cdot \mathrm{Q}_{1,(\mathrm{H}-\mathrm{Zn})}^{*}{ }^{2 / 3}\right)}
$$

と表すことができる。

注9）実験から得られた鉛直壁面近傍温度を無次元化した分布が実線上の $\mathrm{T}^{*} \approx 0.6$ で一致するよう、実験条件ごとに未燃ガスの発熱量 $\mathrm{Q}_{\mathrm{ef}}$ の值を 変化させ求めた。

注10）式 (20)の $z^{*} \leqq 1.4$ の条件は、自由空間中に沶ける乱流拡散火炎の連

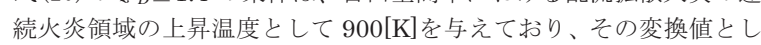
て $\mathrm{x} \leqq 0.88$ の条件では、 $\mathrm{T}^{*}=1.205$ を与えているが、噴出熱気流の場 合、開口付近の $T^{*}$ は区画内火災温度から式 (26) を用い算定する方法 が考えられる。

\section{参考文献}

1）大宮喜文：内外装の火災安全性能, 建築雑誌, 日本建築学会 vol. 131, No. 1683 , pp. 24-25, 2016. 4

2）空から見直せ，日経アーキテクチュア一，No, 1017 pp. 28-44, 2014.2

3）三澤温, 彦根茂, 油野健志, 大宮喜文, 岩本靜男, 岩田衛 : 統合ファサ 一ドにおける斜行ルーバーに関する実大火炎実験 一斜行ルーバー近傍 の開口噴出気流性状-, 日本建築学会技術報告集, 第 16 巻, 第 33 号, pp. 547-552, 2010. 6

4）竹内徹, 小谷野一尚, 安田幸一, 湯浅和博, 岩田衛: ファサードエンジ ニアリングの統合に関する研究：統合ファサードの提案および性能評 価，日本建築学会環境系論文集，第 601 号，pp.81-88，2006.3

5）平井健嗣, 今井大樹, 李祥準, 堤洋樹, 小松幸夫, 新谷眞人 : 既存建築 物の長寿命化を視野に入れた改修手法に関する研究 一外断熱改修の実 測調査による温度応力から見た長寿命化への可能性-, 日本建築学会計 画系論文集，第 76 巻，第 659 号, pp. 167-177, 2011. 1

6）吉岡英樹, 楊欣潔, 田村政道, 吉田正志, 野口貴文, 兼松学, 小浦孝次, 尾崎泰治: 外断熱工法外壁の燃え拡がり性状を評価する新しい試験方法 の検討, 日本建築学会技術報告集, 第 17 巻, 第 36 号, pp. 534-542, 2011.6

7）吉岡英樹, 尾崎泰治, 西尾悠平, 田村政道, 吉田正志, 野口貴文, 兼松 学, 安藤達夫, 小浦孝次, 富松太基 : 可燃性外装の燃え拡がり性状に関 するファサード型火災実験，日本建築学会技術報告集，第 19 巻，第 42 号, pp. 595-600, 2013.6

8) S. Yokoi : Study on the Prevention of Fire-Spread Caused by Hot Upward Current，建設省建築研究所建築研究報告 No. 34, 1960

9) T. Yamada, K. Takahashi, E. Yanai, T. Suzuki, A. Sekizawa : An Experimental study of Ejected Flames and Combustion Efficiency, Fire Safety Science, Proc. $7^{\text {th }}$ International Symposium, pp. 904-914, 2002.6
10) Keisuke Himoto' Takeyoshi Tanaka: Development and validation of a physics-based urban fire spread model, Fire Safety Journal, Vol. 43, Issue 7, pp. 477-494, 2008. 10

11) Y. P. Lee, M. A. Delichatsios, G. Silcock: Heat fluxes and flame heights in facades from fires in enclosures of varying geometry : Proc. Combust. Inst. 31, pp. 2521-2528, 2007

12) J. Ymaguchi, T. Tanaka : Temperature Profiles of Window Jet Plume, Fire Science and Technology, Vol.24, No. 1, pp. 17-38, 2005

13) I. Oleszkiewicz: Fire exposure to exterior walls and flame spread on combustible cladding, Fire Technology, Volume 26, Issue 4, pp. 357-375, 1990. 11

14) K. H. Lu, L.H.Hun, F. Tang, L. H. He, X. C. Zhang, Z. W. Qiu : Heat flux profile upon building façade with side walls due to window ejected fire plume : An experimental investigation and global correlation, Fire Safety Journal, Vol. 70, pp. 14-22, 2014.11

15）山口純一，岩井裕子，田中哮義，原田和典，大宮喜文，若松孝旺：開口 噴出気流温度の相似則としての無次元温度の適用性, 日本建築学会計画 系論文集，第 513 号，pp. 1-7，1998.11

16）大宮喜文，堀雄兒：火災区画外への余㮃未然ガスを考慮した開口噴出火 炎性状，日本建築学会計画系論文集第 545 号, pp. 1-8, 2001.7

17) J.G.Quintiere :Principles of Fire Behavior, Delmar Publishers, 1998

18）横井鎮雄: 熱源からの上昇気流について(流速および温度の水平分布式), 日本火災学会論文集, Vol. 4, No. 1, pp. 1-3, pp. 13, 1954

19) S. Yokoi : Study on the Prevention of Fire-Spread Caused by Hot Upward Current , Building Research Institute, Research Report No. 34, 1960

20) B. R. Morton, G. I. Taylor and J. S. Turner : Turbulent Gravitational Convection from Maintained and Instantaneous Sources, Proc. of Royal Society, A234, 1956

21) B. M. Cetegen, E. E. Zukoski and T. Kubota : Entrainment in the Near and far Field of Fire Plumes, Combustion Science and Technology, Vol. 39, pp. 305-331, 1982

22）横井鎮男：耐火造火災時の窓からの噴出気流のトラジェクトリ，日本火 災学会論文集, Vol.8, No. 1, pp. 1-5，1958

23）横井鎮男：耐火造火災実験報告（横に長い形の空から噴出する火焔の性 状），日本火災学会論文集，Vol.9, No. 1, pp. 1-5, 1959

24) Junichi Yamaguchi, Takeyoshi Tanaka: Temperature Profiles of Window Jet Plume, Fire Science and Technology, Vol.24, No. 1, 2005

25）横井鎮男：耐火造火炎時の窓からの噴出気流の温度分布，日本火災学会 論文集，Vol.7，No. 2，pp. 41-45，1958

26）山口純一，岩井裕子，田中哮義，原田和典，大宮喜文，若松孝旺：開口 噴出熱気流温度の相似則としての無次元温度の適用性, 日本建築学会計 画系論文集，No. 513，pp.1-7, 1998. 11

27) Dougal Drysdale: An Introduction to FIRE DYNAMICS, Third Edition, Wiley, 2012

28）原田和典 : 建築火災のメカニズムと火災安全設計, 財団法人日本建築セ ンター, pp39-41, 2007. 12 


\title{
TEMPERATURE DISTRIBUTION IN THE VICINITY OF VERTICAL WALL ON OPENING FIRE PLUME EJECTED FROM HORIZONTAL OPENING
}

\author{
Yoshifumi OHMIYA* , Yi-chul SHIN ${ }^{* *}$, Masaki NOAKI *** \\ and Seung-goo KANG ${ }^{* * * *}$ \\ * Prof., Dept. of Architecture, Faculty of Science and Technology, Tokyo University of Science, Dr.Eng. \\ ** Research Specialist, Korea Institute of Civil Engineering and Building Technology, Dr.Eng. \\ *** Researcher, Building Research Institute, Dr.Eng. \\ **** Grad. Stud., Graduate School of Global Fire Science and Technology, Tokyo University of Science
}

Fire plume ejected from an opening tend to have a central axis of air current that rises closer to the wall surface as the cross-sectional shape of the opening (hereinafter ,horizontal opening) becomes more horizontal. Fire plume ejected from such openings increase the potential risk of fire spreading to upper floors. Furthermore, fire plume from an opening may become longer due to increased thermal decomposition of combustible materials inside the compartment and the effect of pyrolysis gas burning outside the building.

Currently in building design practice in Japan, the method proposed by Yokoi is generally used when investigating measures for preventing the spread of fire to the upper floors due to fire plumes from openings in buildings. However, the opening conditions that Yokoi examined covered aspect ratios $n=2 W / H$ (W: width of opening; $H$ : height of opening) of up to around 6.4, whereas the openings in modern buildings may have openings with aspect ratios greater than 6.4. Furthermore, although the amount of pyrolysis gas emitted from the opening is expected to increase with increased amounts of flammable material brought into the building, the Yokoi method is unable to take into account such changes in the amount of pyrolysis gas.

The focus of this research was therefore placed on the shape of the plumes of hot air under various flammable material conditions for openings with a horizontal shape. A series of experiments using a full-size compartment focusing on the shape of the temperature distribution in order to obtain knowledge related to the shape of the temperature distribution were conducted.

In the experiment, we aimed to determine the temperature distribution above horizontal openings with aspect ratios of $n=5 \sim 20$. The experimental apparatus consisted of a combustion compartment and a facade for modeling a room on fire. The dimensions of the combustion compartment were $4000[\mathrm{~mm}]$ wide $\times 4000[\mathrm{~mm}]$ deep $\times 1700[\mathrm{~mm}]$ high. The shape of the opening was fixed with opening widths of $2[\mathrm{~m}]$ and $3.7[\mathrm{~m}]$, and the opening aspect ratio was set in the range $n=5 \sim 20$ in six sets of conditions for the opening width of $2[\mathrm{~m}]$ and three sets of conditions for the opening width of $3.7[\mathrm{~m}]$. Three different fuels were used for the heat source: methanol, ethanol, and heptane.

The following was found from this study.

- Temperature attenuated with height $Z$ above the opening to essentially the -1 power, the same as the gradient of the temperature distribution of the rectangular heat source.

- The temperature distribution near the wall above the opening, nondimensionalized by taking $T^{*}$ for the vertical axis and $Q^{*}{ }_{(H-Z n)}^{-2 / 3} Z_{(H-Z n)}{ }^{*}$ for the horizontal axis, exhibited a correlation with the temperature distribution of the rectangular heat source in free space when using the amount of heat $Q_{\text {ef }}$ generated by pyrolysis gas.

- $Q_{\text {ef,max }}$ may underestimate the amount of heat generated by the pyrolysis gas. When $Q_{\text {ef,crit }}$ was used, under the conditions where ethanol and heptane were used, the calculated and experimental values tended to match well. 